\title{
Сравнение режимов синхронизации мод в гольмиевом волоконном лазере
}

\author{
С.А. Филатова ${ }^{1, *}$, В.А. Камынин ${ }^{1}$, Н.Р. Арутюнян ${ }^{1,2}$, А.С. Пожаров ${ }^{1}$, \\ Е.Д. Образцова ${ }^{1,3}$, В.Б. Цветков ${ }^{1,2}$ \\ ${ }^{1}$ Институт общей физики имени А. М. Прохорова Российской академии наук, ИОФ РАН \\ ${ }^{2}$ Национальный исследовательский ядерньй университет «МИФИ» \\ ${ }^{3}$ Московский физико-технический институт (государственный университет), МФТИ \\ *E-mail: filsim2910@gmail.com
}

DOI:10.31868/RFL2018.158-159

Много внимания уделяется исследованию и развитию волоконных лазеров, генерирующих ультракороткое излучение в спектральном диапазоне более 2 мкм. Интерес к этим источникам обусловлен широкой областью их возможных применений [1]. Для достижения больших длин волн в двухмикронном диапазоне в качестве активной среды используют волокна, легированные ионами гольмия [2]. Режим синхронизации мод в импульсных гольмиевых волоконных лазерах в основном реализован за счет медленных насыщающихся поглотителей, таких как: углеродные нанотрубки [3], графен [4], самопросветляющиеся зеркала (SESAM) [5]. Однако, исходя из работ, посвященных эрбиевым и тулиевым волоконным лазерам, для достижения самозапуска лазера и стабильной генерации коротких импульсов следует использовать гибридную синхронизацию мод, основанную на совместном использовании медленного насыщающегося поглотителя и быстрого поглотителя, основанного на нелинейном эффекте Керра [6].

В данной работе мы сравниваем режимы синхронизации мод в гольмиевом волоконном лазере, основанные на нелинейном вращении плоскости поляризации (НВПП) [7], и на совместном действии НВПП и насыщающегося поглотителя на основе одностенных углеродных нанотрубок.

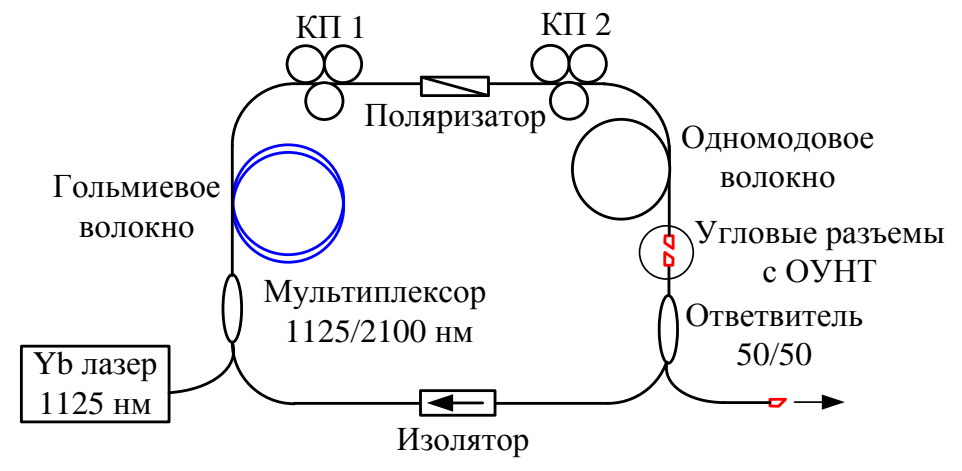

Рис.1 Схема гольмиевого волоконного лазера с гибридной синхронизацией мод.

КП 1,2 - контроллеры поляризации, ОУНТ - одностенные углеродные нанотрубки.

На Рис. 1 представлена оптическая схема гольмиевого волоконного лазера с гибридной синхронизацией мод. Накачка гольмиевого лазера осуществлялась непрерывным излучением от иттербиевого волоконного лазера на длине волны 1125 нм через мультиплексор 1125/2100 нм. Кольцевой резонатор, длиной около 20 м состоял из гольмиевого волокна, длиной около 6 м, и одномодового волокна Corning SM-332. Волоконный поляризатор и пара контроллеров поляризации помещались между активным и одномодовым волокном для формирования НВПП. В качестве медленного насыщающегося поглотителя использовались 
одностенные углеродные нанотрубки (ОУНТ), нанесенные на полимерную пленку, которая фиксировалась между двумя угловыми разъемами. Волоконный ответвитель 50/50 использовался в качестве вывода лазерного излучения. Схема гольмиевого лазера с синхронизацией мод за счет НВПП отличалась лишь отсутствием пленки с ОУНТ между оптическими разъемами.

На Рис. 2 представлены спектры излучения гольмиевых волоконных лазеров при разных режимах синхронизации мод. Спектры имеют типичную форму для солитонного режима работы лазеров, соответствующего аномальной внутрирезонаторной дисперсии. Из Рис. 2 видно, что центральные длины волн и ширина спектров на полувысоте отличаются.

a)

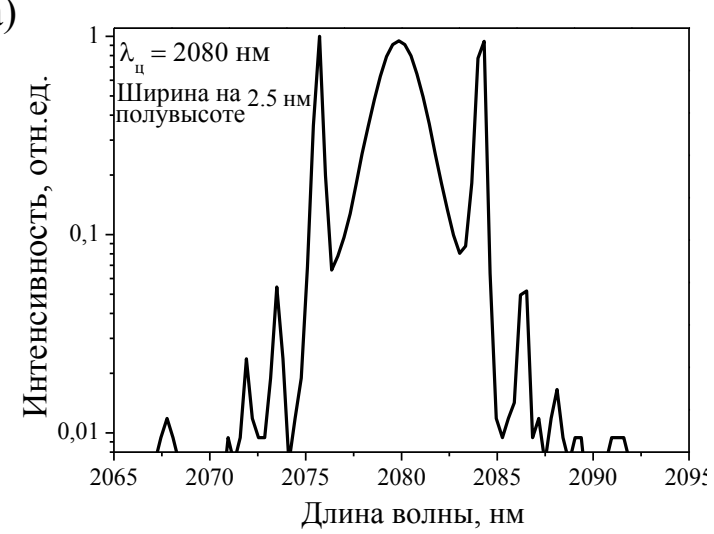

б)

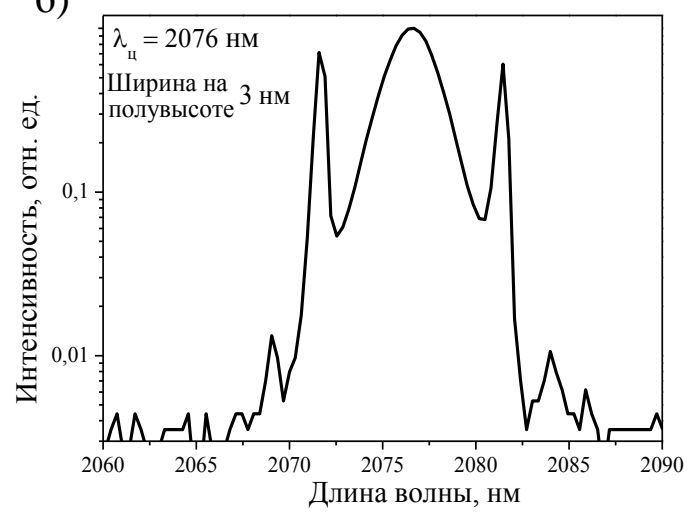

Рис. 2 Спектры излучения гольмиевых волоконных лазеров:

a) с синхронизацией мод на основе НВПП, б) с гибридной синхронизацией мод на основе НВПП и ОУНТ.

В работе проведено сравнение различных режимов синхронизации мод (на основе НВПП, а также на основе НВПП и ОУНТ) в гольмиевом волоконном лазере. Проведено сравнение спектральных и временных параметров лазерного излучения, а также изучен вопрос стабильности лазерной генерации.

Работа выполнена при поддержке Президиума Российской Академии Наук в рамках программы фундаментальных исследований № I.7 «Актуальные проблемы фотоники, зондирование неоднородных сред и материалов».

\section{Литература}

[1] K. Scholle, S. Lamrini et al., in Frontiers in Guided Wave Optics and Optoelectronics, Bishnu Pal, ed., 471-500 (InTech, 2010);

[2] A. Hemming, N. Simakov et al., Optical Fiber Technology 20(6), 621-630 (2014);

[3] A.Y. Chamorovski, A.V. Marakulin et al., Laser Phys. Lett. 9(8), 602-606 (2012);

[4] J. Sotor, M. Sobon et al., Optics letters 41.11, 2592-2595 (2016);

[5] N. Tolstik, E. Sorokin et al., in Mid-Infrared Coherent Sources (pp. MM6C-4), Optical Society of America (2016);

[6] M.A. Chernysheva, A.A. Krylov et al., IEEE journal of selected topics in quantum electronics 20(5), 425-432 (2014);

[7] S.A. Filatova, V.A. Kamynin et al., Laser Physics Letters 13(11), 115103 (2016). 